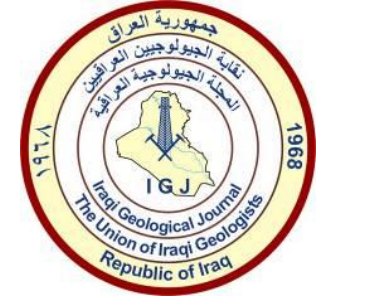

Iraqi Geological Journal

Journal homepage: https://www.igj-iraq.org

\title{
Estimation of the Radioactive Elements in Raw Materials Utilized in the Ceramic Industry, Anbar, Western Iraq
}

\author{
Ahmed O. Farhan', Ahmed M. Ahmed ${ }^{2, *}$ and Sabah. S. Farhan ${ }^{1}$ \\ Renewable Energy Research Center, University of Anbar, Ramadi, Iraq \\ Department of Physics, College of Science, University of Anbar, Ramadi, Iraq \\ Correspondence: sc.ahmedmud76@uoanbar.edu.iq
}

\begin{abstract}
Received:

17 October 2021

In the present study, The High-Purity Germanium system was utilized to Radionuclide concentrations of 10 specimens of raw materials utilized in the ceramic manufacture from the ceramic plant in Anbar, western Iraq. The concentrations ranged between 15.035-

Accepted:

21 November 2021

Published:

28 February 2022 $31.410,11.330-33.870,85.380-272.320 \mathrm{~Bq} / \mathrm{kg}$ of ${ }^{238} \mathrm{U},{ }^{232} \mathrm{Th}$ and ${ }^{40} \mathrm{~K}$, respectively, with an aggregate rate of $23.523 \pm 4.121,23.616 \pm 5.308,176.084 \pm 58.848 \mathrm{~Bq} / \mathrm{kg}$, respectively. The radiological aspects Were discussed by computing the gamma radiance parameters. Consequently, the qualitative activity level and gamma radiance parameters are less than the authorized Global Rate's worth of US Environmental Protection Agency (US EPA) standards. The prospective source of ${ }^{238} \mathrm{U},{ }^{232} \mathrm{Th}$, and ${ }^{40} \mathrm{~K}$ in raw material specimens Has contained specimens a small number of radioactive minerals like monazite, chromite, zircon, tourmaline, titanite, and apatite, there are no appreciable radiation hazard indices to personnel's in the raw material department of the study region. The research recommends proposing new Iraqi standards that specify the permissible percentages of qualitative activity concentration also gamma radiance parameters to preserve the environment and human health, especially that the ceramics plant is located in Al-Anbar center.
\end{abstract}

Keywords: Raw materials; High-purity germanium system; Ceramic plant; Al-Anbar

\section{Introduction}

humans are constantly presented to natural radiation, which is mostly because of the activity of characteristic radionuclides $238 \mathrm{U}$ (226Ra), 232Th chains, the radioactive isotope $40 \mathrm{~K}$, and their radioactive decay products that can be found in the earth are outside layer such as rocks, mineral ores, in building supplies, air, water, food also in the human body (Unscear, 2019; HPS, 2015; Ahmed and Farhan, 2022; Farhan et al., 2020). Gamma radiance is the most dangerous and harmful source for the human body, which is released by these naturally produced radionuclides (Kuzmanović et al., 2020; Fawaz and Ahmed, 2014). Natural radioactivity can be present in varying amounts in different geological formations, contingent upon its source, geochemical climate, and rock type. Generally, the raw materials utilized to make ceramics reflect the geology of their original region (Ahmed and Farhan, 2022 and Taskin et al., 2009). Although this radiation is contained within relatively narrow limits, and Iraq is situated within these regions, there are some variations from normal levels due to the existence of abnormally high concentrations of radioactive minerals, as in the case of phosphate rocks containing high concentrations of 238U in Iraq's western region (Farhan et al., 2020; Cottingham and Greenwood,

DOI: 10.46717/igj.55.1B.11Ms-2022-02-27 
2006 and Oriel, 2003). The 238U decomposes by emitting alpha particles, which harm interior body cells when inhalation or inhalation of uranium (Jassam and Awadh, 2021). So, exposure to alpha and beta particles as a result of inhalation of non-soluble uranium particles may harm lung tissue and raise the hazard of lung cancer (CPEP, 2003). When inhalation via the digestive system, it has a double influence, as uranium is a heavy metal, also a radioactive metal (WHO, 2001). Raw material's radioactivity relies upon the minerals utilized in their manufacture (Kuzmanović et al., 2020). For instance, Ceramic tile radioactivity relies upon the radioactivity of the raw materials utilized in their manufacture (feldspar, bauxite, dolomite, kaolin, quartz, sand, glazes, white mud, red mud, and black mud) (Luo et al., 2017 and Al-kubaisi and Farhan, 2018). Consequently, the measurement of radioactivity in raw materials is very significant for evaluating environmental dangers to human health also is essential for evaluating standard radiation levels and national guidance in conformity with international standards (Ali, 2012).

Since the personnel's in the raw materials depots come into close touch with these materials, the only thing that can be done is try to prevent radioactive elements from entering the body in quantities that exceed the permitted limit. So, the research aims to evaluate the qualitative activity of radioisotopes $238 \mathrm{U}, 232 \mathrm{Th}, 40 \mathrm{~K}$ in the raw materials utilized in the ceramic plant and to monitor natural radioactivity for the detection of radioactive ores also evaluate the radiation hazard indicators of gamma and distinguish between the worth of the minerals found in nature and how they are handled due to their influence on human health and the environment.

\section{Materials and Methods}

The 10 various specimens of the raw materials utilized in the ceramic manufacture were gathered from the ceramic plant in Anbar, western Iraq, including, feldspar is a combination of rock-forming minerals that make up about $60 \%$ of the outer surface of the Earth, helping to give transparency to the outer layer of ceramics, spreading in the Khan al-Nasr region of Najaf province. Bauxite is one of the significant ores from which aluminum (Al) is extracted, which enters the ceramic manufacture because it is stainless, lightweight, and non-toxic, it is concentrated in Anbar province, western Iraq (Awadh and Khalid, 2019). Dolomite gives ceramics the hardness needed to contain $\mathrm{CaO}$ and is brought from Kubaisa quarries in Anbar, western Iraq. Kaolin is a type of fine, soft, white rock, containing $\left(\mathrm{Fe}_{2} \mathrm{O}_{3}\right)$ at a rate not exceeding 1\%. It is concentrated in Anbar province, in the Western Desert region, in the Duwikhala region, particularly in the northeast of Rutbah (Awadh and Yousif, 2015). Quartz and Sand are major materials in ceramic manufacture, and each contains a large amount of $\mathrm{SiO}_{2} \mathrm{Up}$ to $80 \%$. It is concentrated in the Western Sahara region of Anbar province, western Iraq. The glaze is a glass material utilized to coat the outer layer of ceramics and it is burned on ceramic surfaces to be covered to melt on the surface and form a specular glazed layer or coated over the ceramic body. White mud usually contains in its mineral composition $\mathrm{CaCO}_{3}, \mathrm{CaSO}_{4}$, and $\mathrm{SiO}_{2}$, red mud contains a high ratio of $\mathrm{FeO}$ mineral, black mud usually contains in its mineral composition of $\mathrm{Mn}$, this color due to large quantities of organic compounds containing carbon. In addition to some colored materials and some improved ceramic quality materials such as $\mathrm{NaOH}, \mathrm{Na}_{2} \mathrm{SiO}_{3}, \mathrm{CaCO}_{3}$, and lubricants.

All specimens (raw materials) were crushed utilizing an electric mill and dried by exposing them to sun heat to remove moisture residues from them, after which a sieve with $500 \mu \mathrm{m}$ in diameter was utilized to sieve the specimens to obtain a smooth and homogeneous powder, each specimen was weighed utilizing a sensitive digital balance. Plastic beakers with a capacity of $1 \mathrm{~L}$ were utilized to gather weighted specimens and the beakers were washed with diluted hydrochloric acid as acid reduces the absorption of radionuclides on the walls of the beaker. Plastic beakers were tightly sealed, the specimen type fixed, and stored for about 30 days prior to counting to achieve secular equilibrium. Utilizing a 
low-background gamma radiation detection device, the specimens were then calibrated to determine the accumulated vestige of radioactive elements.

\section{High Purity Germanium (HPGe) Radiation Detection System}

The pure germanium detector and multi-channel spectra analyzer produced by Canberra company and type GC-2520 were utilized to analyze the specimen containing radioactive elements for such good qualities as its high density $\left(5.3 \mathrm{gm} / \mathrm{cm}^{3}\right)$ that it possesses high nuclear-beam stopping power in small volumes of matter, which increases its efficiency, it is an efficient semiconductor detector (50\%) and an analytic capability $(2.2 \mathrm{KeV})$ at the energy $(1332 \mathrm{KeV})$ of isotope ${ }^{60} \mathrm{Co}$. The counter operates with a positive operating voltage $(+2000 \mathrm{~V})$ and cools this type of detector when operating to a temperature $\left(77^{\circ} \mathrm{K}\right)$ by a liquid nitrogen reservoir to keep the detector crystalline at work and reduce noise. The detector is surrounded by a $10 \mathrm{~cm}$ shield of lead $(\mathrm{Pb})$ to reduce the influence of the natural radiance background upon the detector's performance. The detector's interface from the inside is coated with a layer of iron, copper, and aluminum in thickness $(0.1 \mathrm{~cm})$ each to attenuation the $\mathrm{X}$ - beams from the interaction of the gamma beams with the lead material. The system is configured for measurement as in Fig. 1. The genie 2000/ version 3.1 program, which is an integrated program of qualitative and quantitative analyses, has been utilized to find the qualitative radioactivity of the absolute nuclides of the specimen gamma beams.

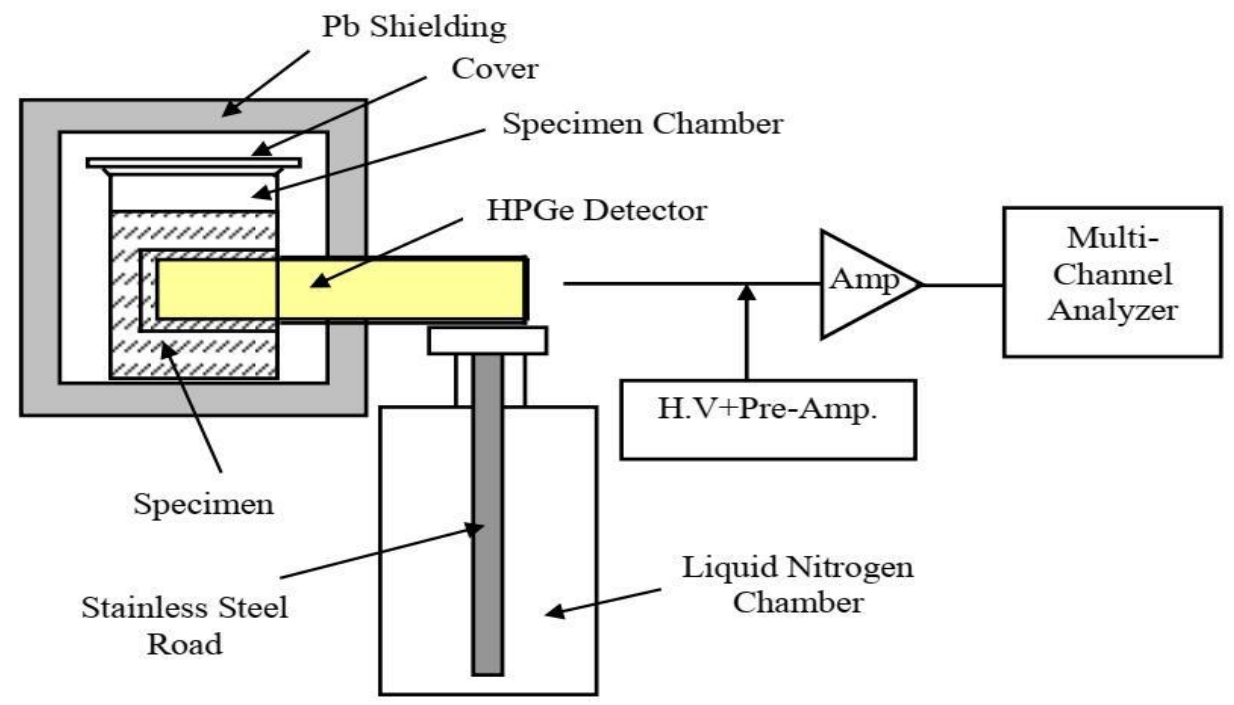

Fig. 1. schematic diagram of (HPGe) system

\section{Qualitative Activity Evaluation}

It is characterized as the radiological activity through a unit mass of a radionuclide substance. The qualitative activity in units $(\mathrm{Bq} / \mathrm{kg})$ for distinguished Radionuclide; it may be expressed utilizing the relationship below (Dovlete and Povinec, 2004):

$$
\text { Qualitative Activity }=\frac{N}{M \times I_{\gamma} \times E f f . \times t}
$$

Where $\mathrm{N}$ is the region under the photopeak at a particular energy, $\mathrm{M}$ is the mass of an inspected specimen $(\mathrm{kg})$, I $\gamma$ is percentage intensity of $\gamma$ - beam impetuous probability, Eff. is the estimated detector efficiency at particular energy and $t$ is time for the detector to be recorded (sec). 


\section{Evaluations of some Gamma Radiance Parameters}

Gamma Radiance Parameters are often utilized to evaluate the amount of radioactive contamination on the personnel or workplace considered. All limitations of radioactive contamination indicators, which differ from indication to indicator based on qualitative activity for of $238 \mathrm{U}, 232 \mathrm{Th}$, and $40 \mathrm{~K}$, have been defined with fixed worth, if those worth at a given location exceeds that limit, that location is classified as a radioactive hazard region.

\section{1. Radium Identical Activity (Ra id. $_{\text {. }}$}

Due to the irregular distribution of radionuclides in the raw materials specimens, utilize a radiometric coefficient called radium identical activity to include a regular distribution of these radionuclides symbolized by $238 \mathrm{U}, 232 \mathrm{Th}$, and $40 \mathrm{~K}$. The radium identical activity (Raid) in Bq/kg units of a specimen may be computed from the formula below (Beretka and Mathew, 1985):

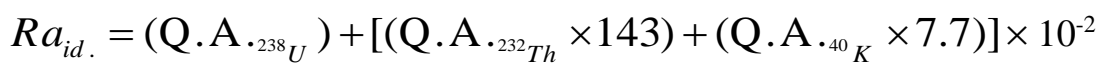

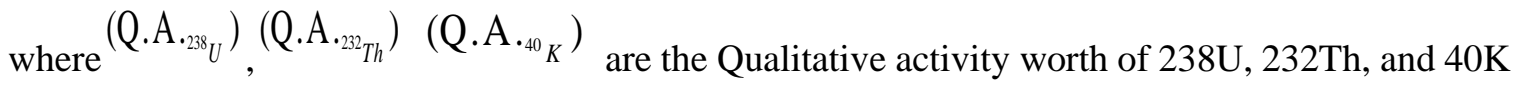
respectively.

\subsection{Inhalation Gamma Dose in $\operatorname{Air}\left(D_{\gamma}\right)$}

The quantity of energy absorbed by a person or an item as a consequence of radiation is known as the inhalation gamma dose in air. The Qualitative activity of $238 \mathrm{U}, 232 \mathrm{Th}$, and $40 \mathrm{~K}$ may be utilized to compute the inhalation gamma dose in air at (1) meter above the Earth's surface, according to criteria provided by reference (Unscear, 2019). They assumed that secessions from other normally occurring radionuclides have been significant. As a result, D $\gamma(\mathrm{nGy} / \mathrm{h})$ unit of a specimen may be computed as follows (Krstić et al., 2007):

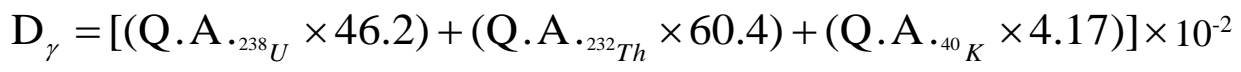

\subsection{Yearly Effective Dose Identical (YEDI)}

To assess the range of the health traces due to the inhalation gamma dose in air, utilize a radiometric coefficient known as the yearly effective dose identical. The estimated yearly effective dose identical person receives is computed via utilizing a transformation coefficient of $0.7 \mathrm{~Sv} / \mathrm{Gy}$, to transform the inhalation gamma dose in air to yearly effective dose identical of outer ownership of $20 \%$ and also an $80 \%$ for inner. Accordingly, The YEDI (mSv/y) unit of a specimen may be computed from the formula below (Dovlete and Povinec, 2004):

$$
\begin{aligned}
& \mathrm{YEDI}_{\text {In }}=\mathrm{D}_{\gamma} \times 8.760 h / y \times 0.8 \times 0.7 \times 10^{-3} \\
& \mathrm{YEDI}_{\text {Out }}=\mathrm{D}_{\gamma} \times 8.760 h / y \times 0.2 \times 0.7 \times 10^{-3}
\end{aligned}
$$

\subsection{Gamma Radiation Activity Index (I $\gamma$ )}

To assess the levels of gamma $(\gamma)$ irradiation hazard correlated with gamma natural emissions in the raw materials specimens, utilize a radiometric coefficient known as the gamma radiation activity index. The gamma radiation activity index (I $\gamma$ ) is computed as follows (Beretka and Mathew, 1985): 


$$
I_{\gamma}=\frac{\mathrm{Q} \cdot A \cdot{ }_{238} U}{300}+\frac{\mathrm{Q} \cdot A \cdot{ }_{{ }_{232} T h}}{200}+\frac{\mathrm{Q} \cdot A \cdot{ }_{40} K}{3000}
$$

The quantity of $\mathrm{I}_{\gamma}$ must've been smaller than one so to reduce any danger of radiation.

\subsection{Radiation Hazard Indices (H)}

To assess the irradiation hazards exemplified by the ionizing hazard of regular gamma radiation, utilize a radiometric coefficient known as the exterior hazard indices (Hex), Which may be inferred from the relationship (Krstić et al., 2007):

$$
H_{e x}=\frac{\mathrm{Q} \cdot A \cdot{ }_{238} U}{370}+\frac{\mathrm{Q} \cdot A \cdot{ }_{232} T h}{259}+\frac{\mathrm{Q} \cdot A \cdot{ }_{40} K}{4810}
$$

In contrast to the exterior danger indices, ${ }^{222} \mathrm{Rn}$ and its short-lived emissions are dangerous to the lungs. The interior interaction between radon $\left({ }^{222} \mathrm{Rn}\right)$ and its daughter emissions are characterized via interior hazard indices $\left(\mathrm{H}_{\mathrm{in}}\right)$, that can be explained by the relationship (Krstić et al., 2007):

$$
H_{i n}=\frac{\mathrm{Q} \cdot A \cdot{ }_{238} U}{185}+\frac{\mathrm{Q} \cdot A \cdot{ }_{232} T h}{259}+\frac{\mathrm{Q} \cdot A \cdot{ }^{40} K}{4810}
$$

\section{Results and Discussion}

The 10 specimens of raw materials utilized in ceramic manufacture were gathered from the ceramic plant in Anbar, western Iraq. Detection of radionuclides and measurement of qualitative radioactivity (238U, 232Th, and 40K) and gamma radiance parameters were computed utilizing the $\gamma$-beams spectroscopy with HPGe detector.

The minimal worth of ${ }^{238} \mathrm{U},{ }^{232} \mathrm{Th}$, and $\mathrm{Ra}_{\mathrm{id}}$ approximately to $15.035,11.330$ and $41.981 \mathrm{~Bq} / \mathrm{kg}$ respectively in glaze's specimen, The minimal worth of ${ }^{40} \mathrm{~K}$ and $\mathrm{D}_{\gamma}$ approximately to $85.380 \mathrm{~Bq} / \mathrm{kg}$ and $19.429 \mathrm{nGy} / \mathrm{h}$ respectively in feldspar specimen. the most elevated worth of ${ }^{238} \mathrm{U},{ }^{232} \mathrm{Th},{ }^{40} \mathrm{~K}, \mathrm{Ra}$ id, and $\mathrm{D}_{\gamma}$ approximately to $31.410,33.870,272.320,100.813 \mathrm{~Bq} / \mathrm{kg}$ and $46.325 \mathrm{nGy} / \mathrm{h}$ respectively in the sand specimen, as in Fig. 2. In sand specimen, The most elevated worth appearance also discovered a relative disparity of ${ }^{238} \mathrm{U},{ }^{232} \mathrm{Th},{ }^{40} \mathrm{~K}, \mathrm{Ra}_{\mathrm{id}}$, and $\mathrm{D}_{\gamma}$ within the recommended level of US Environmental Protection Agency standards (US EPA, 2014), This is attributed to the reason that they contain a small number of radioactive minerals like monazite, chromite, zircon, tourmaline, titanite, and apatite, It is a major source of radionuclides ${ }^{238} \mathrm{U}\left({ }^{226} \mathrm{Ra}\right)$ and ${ }^{232} \mathrm{Th}$. the aggregate rate of ${ }^{238} \mathrm{U},{ }^{232} \mathrm{Th},{ }^{40} \mathrm{~K}, \mathrm{Ra}$ id , and $\mathrm{D}_{\gamma}$ approximately to $23.523 \pm 4.121,23.616 \pm 5.308,176.084 \pm 58.848,70.852 \pm 14.414 \mathrm{~Bq} / \mathrm{kg}$ and $32.474 \pm 6.680 \mathrm{nGy} / \mathrm{h}$ respectively as in Table 1 . The latest findings clarify that the rate of ${ }^{238} \mathrm{U},{ }^{232} \mathrm{Th},{ }^{40} \mathrm{~K}, \mathrm{R} \mathrm{a}_{\mathrm{id}}$, and $\mathrm{D}_{\gamma}$ in raw materials specimens was less than the authorized Global Rate's worth approximately to 35, 30, 400, 370 $\mathrm{Bq} / \mathrm{kg}$ and $55 \mathrm{nGy} / \mathrm{h}$ respectively (US EPA, 2014).

The minimal worth of yearly effective dose identical (YEDI) (inner and outer) and gamma radiation activity index $\left(\mathrm{I}_{\gamma}\right)$ approximately to $0.095,0.024 \mathrm{mSv} / \mathrm{y}$ and 0.151 respectively in feldspar specimen. The minimal worth of radiation hazard indices $(\mathrm{H})$ (interior and exterior) approximately to 0.154 and 0.113 in Glaze's specimen. the most elevated worth of $\mathrm{YEDI}_{\mathrm{in} \text {, out, }} \mathrm{I}_{\gamma}$ and $\mathrm{H}_{\mathrm{in} \text {, ex }}$ approximately to 0.227 , $0.057 \mathrm{mSv} / \mathrm{y},(0.365,0.357$ and 0.272$)$ respectively in a sand specimen, as in Fig. 3 and the aggregate rate of $\mathrm{YEDI}_{\text {in, out, }} \mathrm{I}_{\gamma}$ and $\mathrm{H}_{\text {in, ex }}$ approximately to $0.159 \pm 0.033,0.040 \pm 0.008 \mathrm{mSv} / \mathrm{y}, 0.255 \pm 0.053$, $0.255 \pm 0.050$ and $0.191 \pm 0.039$ respectively as in Table 2 . The latest findings clarify that the rate of 
YEDI $_{\text {in, out, }} \mathrm{I}_{\gamma}$ and $\mathrm{H}_{\mathrm{in} \text {, ex }}$ in raw materials specimens was less than the authorized Global Rate's worth approximately to $1 \mathrm{mSv} / \mathrm{y}$ and 1 respectively (USEPA, 2014).

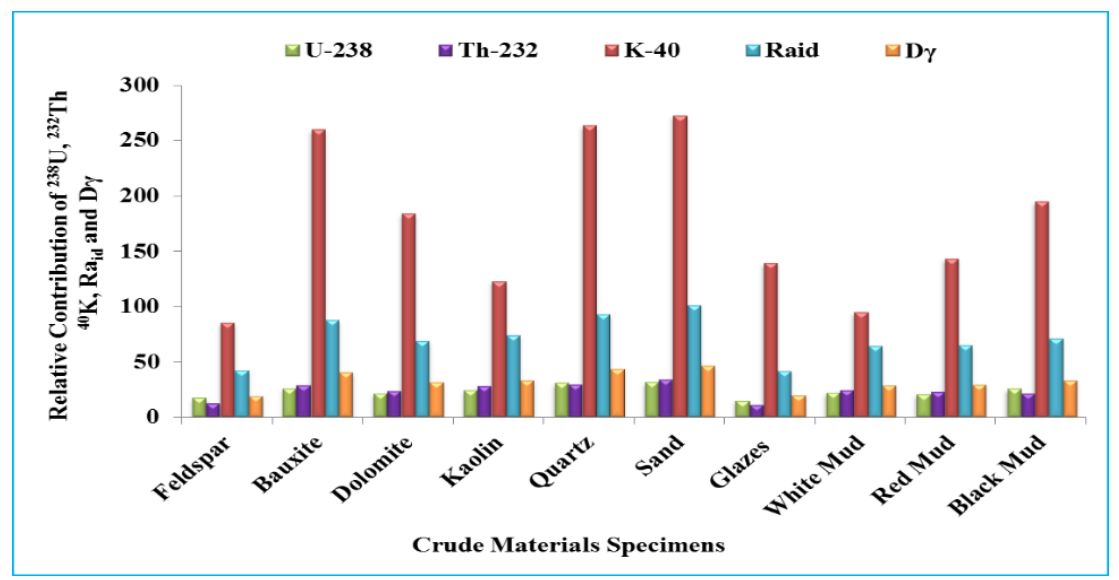

Fig. 2. Relative contribution of ${ }^{238} \mathrm{U},{ }^{232} \mathrm{Th},{ }^{40} \mathrm{~K}, \mathrm{R} \mathrm{a}_{\mathrm{id}}$, and $\mathrm{D}_{\gamma}$ for raw materials specimens utilized in ceramic manufacture

Table 1. The Qualitative Activity (Q. A.), $\mathrm{Ra}_{\mathrm{id}}$ and $\mathrm{D}_{\gamma}$ of raw materials specimens

\begin{tabular}{|c|c|c|c|c|c|}
\hline Specimen Name & $\begin{array}{c}\mathrm{Q} \cdot \mathrm{A} \cdot{ }^{238} U \\
(\mathbf{B q} / \mathbf{K g})\end{array}$ & $\begin{array}{c}\text { Q.A. }{ }_{232} T h \\
(\mathbf{B q} / \mathbf{K g})\end{array}$ & $\begin{array}{l}\mathrm{Q} \cdot \mathrm{A} \cdot{ }^{40} K \\
(\mathbf{B q} / \mathbf{K g})\end{array}$ & $\begin{array}{c}\mathbf{R a}_{\text {id }} \\
(\mathbf{B q} / \mathbf{K g})\end{array}$ & $\begin{array}{c}D_{\gamma} \\
(n G y / h)\end{array}$ \\
\hline Feldspar & 17.835 & 12.630 & 85.380 & 42.470 & 19.429 \\
\hline Bauxite & 26.020 & 28.910 & 260.140 & 87.392 & 40.331 \\
\hline Dolomite & 21.210 & 23.270 & 183.660 & 68.628 & 31.513 \\
\hline Kaolin & 24.430 & 28.020 & 123.040 & 73.973 & 33.342 \\
\hline Quartz & 30.550 & 29.470 & 263.270 & 92.964 & 42.892 \\
\hline Sand & 31.410 & 33.870 & 272.320 & 100.813 & 46.325 \\
\hline Glazes & 15.035 & 11.330 & 139.540 & 41.981 & 19.608 \\
\hline White Mud & 22.210 & 24.350 & 95.060 & 64.350 & 28.932 \\
\hline Red Mud & 20.720 & 23.090 & 143.160 & 64.762 & 29.489 \\
\hline Black Mud & 25.810 & 21.220 & 195.270 & 71.190 & 32.884 \\
\hline \multirow{5}{*}{$\begin{array}{l}\text { Ave. } \\
\text { Min. } \\
\text { Max. } \\
\text { worldwide average } \\
\text { (US EPA, 2014) } \\
\end{array}$} & 23.523 & 23.616 & 176.084 & 70.852 & 32.474 \\
\hline & \pm 4.121 & \pm 5.308 & \pm 58.848 & \pm 14.414 & \pm 6.680 \\
\hline & 15.035 & 11.330 & 85.380 & 41.981 & 19.429 \\
\hline & 31.410 & 33.870 & 272.320 & 100.813 & 46.325 \\
\hline & 35 & 30 & 400 & 370 & 55 \\
\hline & 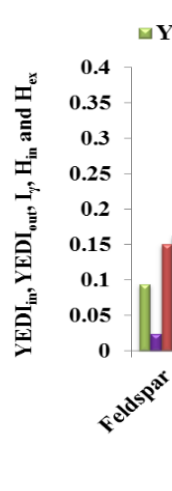 & Crude Materi & $\square$ Hin & & \\
\hline
\end{tabular}

Fig. 3. Yearly Effective Dose Identical (YEDI in, out), (I $\gamma$ ) and (H in, ex) for raw materials specimens utilized in ceramic manufacture 
Table 2. Yearly Effective Dose Identical (YEDI $\left.{ }_{\text {in, out }}\right),\left(\mathrm{I}_{\gamma}\right)$ and $\left(\mathrm{H}_{\mathrm{in}, \mathrm{ex}}\right)$ of raw materials specimens

\begin{tabular}{|c|c|c|c|c|c|}
\hline \multirow[t]{2}{*}{ specimen Name } & \multicolumn{2}{|c|}{$\begin{array}{l}(\text { YEDI) } \\
(\mathrm{mSv} / \mathrm{y})\end{array}$} & \multirow[t]{2}{*}{$\mathbf{I}_{\gamma}$} & \multirow[t]{2}{*}{$\mathbf{H}_{\text {in }}$} & \multirow[t]{2}{*}{$\mathbf{H}_{\text {ex }}$} \\
\hline & $\left(\right.$ YEDI $\left._{\text {in }}\right)$ & (YEDI ${ }_{\text {out }}$ ) & & & \\
\hline Feldspar & 0.095 & 0.024 & 0.151 & 0.163 & 0.115 \\
\hline Bauxite & 0.198 & 0.049 & 0.318 & 0.306 & 0.236 \\
\hline Dolomite & 0.155 & 0.039 & 0.248 & 0.243 & 0.185 \\
\hline Kaolin & 0.164 & 0.041 & 0.263 & 0.266 & 0.200 \\
\hline Quartz & 0.210 & 0.053 & 0.337 & 0.334 & 0.251 \\
\hline Sand & 0.227 & 0.057 & 0.365 & 0.357 & 0.272 \\
\hline Glazes & 0.096 & 0.024 & 0.153 & 0.154 & 0.113 \\
\hline White Mud & 0.142 & 0.035 & 0.227 & 0.234 & 0.174 \\
\hline Red Mud & 0.145 & 0.036 & 0.232 & 0.231 & 0.175 \\
\hline Black Mud & 0.161 & 0.040 & 0.257 & 0.262 & 0.192 \\
\hline Ave. & $\begin{array}{c}0.159 \\
\pm 0.033\end{array}$ & $\begin{array}{c}0.040 \\
\pm 0.008\end{array}$ & $\begin{array}{c}0.255 \\
\pm 0.053\end{array}$ & $\begin{array}{c}0.255 \\
\pm 0.050\end{array}$ & $\begin{array}{c}0.191 \\
\pm 0.039\end{array}$ \\
\hline Min. & 0.095 & 0.024 & 0.151 & 0.154 & 0.113 \\
\hline Max. & 0.227 & 0.057 & 0.365 & 0.357 & 0.272 \\
\hline $\begin{array}{l}\text { worldwide average } \\
\text { (US EPA, 2014) }\end{array}$ & 1 & 1 & 1 & 1 & 1 \\
\hline
\end{tabular}

\section{Conclusions and Recommendations}

This study clarifies the status of raw materials utilized in ceramic manufacture within the study region in terms of qualitative activity accumulations and gamma radiance parameters also their public health implications. In some specimens, it discovered a relative disparity within the recommended level of US Environmental Protection Agency standards (US EPA, 2014) in the qualitative activity concentration and gamma radiance parameters. This is attributed to the reason that they contain a small number of radioactive minerals like monazite, chromite, zircon, tourmaline, titanite, and apatite. It is a major source of radionuclides ${ }^{238} \mathrm{U}\left({ }^{226} \mathrm{Ra}\right)$ and ${ }^{232} \mathrm{Th}$. This study supports numerous recommendations made by this research: Creating large vents that reduce contaminated air and continually release it within 24 hours. The requirement for personnel to undergo a yearly examination to estimate the amount of radiation contained in their bodies, Young people aged (20 - 40) years are chosen and change them at a maximum rate of 3 - 4 years to avoid an increase in radiation accumulation in blood, tissue, and bones, Glass-style clothing is worn to prevent raw materials dust from being lodged in it, Providing enough milk and juices to personnel prior and after of daily work. Collection of wastes and raw materials remains by molding them, melting them in certain forms and covering them with glass to prevent the spread of alpha $(\alpha)$ or beta $(\beta)$ particles.

\section{Acknowledgements}

The authors would like to sincerely thank all the employees of the Ministry of Environment, Gamma Measurements Division (GMD) for their absolute assistance in measuring the concentrations of raw materials specimens utilizing the HPGe system. Also, extend our thanks to the General Company for Glass and Refractories in Ramadi district, and especially Eng. Fouad H. Onaizi, for his assistance during the fieldwork in gathering specimens. The authors are very grateful to the reviewers, Editor in Chief Prof. Dr. Salih M. Awadh, the Secretary of Journal Mr. Samir R. Hijab, and the Technical Editors for their great efforts and valuable comments. 


\section{References}

Ahmed, A. M., Farhan A. O., 2022. Natural radioactivity evaluation and radiological peril in some soil specimens of Al-Taimeem Area in Al-Anbar Province, Iraq. Iraqi Journal of Science, 63 (1).

Ali, K.K., 2012. Radioactivity in building materials in Iraq. Radiation Protection Dosimetry, 148 (3), $372-379$.

Al-kubaisi, A. M. A., Farhan A. O., 2018. Measurement of the radioactivity in raw materials used in the ceramic industry in AL-Ramadi ceramic factory using (HPGe) detector. Iraqi Journal of Science, 59 (1B), 307-313.

Awadh, S.M. and Khalid, S.A., 2019. Tigris river sediments as abrasive for polishing marble. Natural Resources Research, 28(4), 1371-1383.

Awadh, S.M. and Yousif, A.A.H., 2015. Sorption efficiency of kaolinte in removal Cd from aqueous solutions. Iraqi Journal of Science, 56(2C), 1699-1707.

Beretka, J., Mathew, P. J., 1985. Natural radioactivity of Australian building materials, industrial wastes and byproducts. Health Physics, 48 (1), 87-95.

Contemporary Physics Education Project (CPEP), 2003. Nuclear Science - A Guide to the Nuclear Science Wall Chart. Third Edition.

Cottingham, W. N., Greenwood, D. A., 2006. An Introduction to Nuclear Physics. Second Edition, Cambridge University Press.

Dovlete, C., Povinec, P. P., 2004. Quantification of uncertainty in gamma spectrometric analysis of environmental samples. Quantifying uncertainty in nuclear analytical measurements, 103.

Farhan, A. O., Ahmed, A. M., Awadh, S. M., Al-Sultani A. H., 2020. Radon gas and effective dose in groundwater in Abu- Jir Village in Anbar, Western Iraq. Iraqi Geological Journal, 53 (2C), 26-33.

Fawaz, N. I., Ahmed, A., M., 2014. Study the radiation contamination in soil and war waste in the Falluja City Using the solid-state nuclear track detectors (SSNTDs) CR-39. Journal of University of Anbar for Pure science, 8 (3), 98-104.

Health Physics Society (HPS), 2015. Background Radiation: fact sheet (1313), Dolley Madison Blvd., Suite 402, McLean, 22101, 1- 4.

Jassam, H.A. and Awadh, S.M., 2021. Natural Radioactivity in Soil and Bitumen in Al-Marj Spring and Abu-Jir Village, Anbar, Western Iraq. Iraqi Geological Journal, 54 (2E),12-23.

Krstić D, Nikezić D, Stevanović N, Vučić D, 2007. Radioactivity of some domestic and imported building materials from South-Eastern Europe. Radiation Measurements, 42 (10), 1731-1736.

Kuzmanović P., Todorović N., Nikolov J., Knežević J., Miljević B., 2020. Radiological, structural and chemical characterization of raw materials and ceramic tiles in Serbia. Journal of Radioanalytical and Nuclear Chemistry, 323, 861-874.

Luo, Y., Zheng, S., Ma, S., Liu, C., Wang, X., 2017. Ceramic tiles derived from coal fly ash: preparation and mechanical characterization. Ceramics International, 43 (15), 11953-11966.

Oriel, W., 2003. Nuclear Energy. Urban studies program, San Francisco University.

Taskin, H., Karavus, M., Ay, P., Topuzoglu, A., Hidiroglu, S., Karahan, G., 2009. Radionuclide concentrations in soil and lifetime cancer risk due to gamma radioactivity in Kirklareli, Turkey. Journal of Environmental Radioactivity, 100 (1), 49-53.

Unscear, 2019. Sources and effects of ionizing radiation, Report to the General Assembly, with scientific annexes, (United Nations, New York), 1, 1-219.

US Environmental Protection Agency (US EPA), 2014. Memorandum: Human Health Evaluation Manual, Supplemental Guidance: Update of Standard Default Exposure Factors. OSWER Directive 9200.1-120.412.

World Health Organization (WHO), April 2001. Depleted uranium, Sources, Exposure and Health Effects. Department of Protection of the Human Environment, Geneva. 